Insight Biotechnology 1 (1): 1-6, 2011

ISSN 2040-8331

(C) 2011 Insight Knowledge, UK

\title{
Alteration of Protein Patterns in Callus Cultures of Citrullus colocynthis in Relation to Plant Growth Regulators
}

\author{
${ }^{1}$ Amal A. Mohamed, ${ }^{1}$ Farouk K. El-Baz, ${ }^{1}$ Sami I. Ali, ${ }^{2}$ Mahmoud M. Saker and ${ }^{3}$ Ahmad K. Hegazy \\ ${ }^{1}$ Department of Plant Biochemistry, National Research Centre, Dokki, Cairo, Egypt \\ ${ }^{2}$ Department of Plant Biotechnology, National Research Center, Dokkki, Cairo, Egypt \\ ${ }^{3}$ Department of Botany, Faculty of Sciences, Cairo University, Giza, Egypt
}

\begin{abstract}
Callus and cell culture could not only be an alternate continue source of proteins, but could also be a useful and important model system to study their regulation and biosynthesis so, the present study aimed to investigate the effect of different combinations of 2,4 dichloro phenoxy acetic acid (2,4-D) with kinetin (kin) and Benzyl Adenine (BA) with $\alpha$-Naphthalene Acetic Acid (NAA) on: (1) the percentage of callus frequency and (2) protein profiles of Citrullus colocynthis stems, leaves and roots derived callus cultures. The present results reported that the highest percentage of callus frequency ( $98.9 \%$ ) was obtained from stem callus grown on MS media supplemented with $\left(1.0 \mathrm{mg} \mathrm{L}^{-1}\right) 2,4-\mathrm{D}+\left(1.0 \mathrm{mg} \mathrm{L}^{-1}\right)$ kin. Sodium Dodecyl Sulfate (SDS) Polyacrylamide Gel Electrophoresis (PAGE) analysis of total soluble protein revealed expression of new protein band $(65 \mathrm{kDa})$ only in stem derived callus cultured on MS media supplemented with $\left(6.0 \mathrm{mg} \mathrm{L}^{-1}\right)$ 2,4-D $+\left(2.0 \mathrm{mg} \mathrm{L}^{-1}\right)$ kin. Leaf derived callus cultured on MS media supplemented with $\left(2.0 \mathrm{mg} \mathrm{L}^{-1}\right)$ $2,4-\mathrm{D}+\left(1.0 \mathrm{mg} \mathrm{L}^{-1}\right) \mathrm{kin}$ showed new protein band with molecular weight $112 \mathrm{kDa}$. Moreover, the root derived callus revealed expression of new protein band $(82 \mathrm{kDa})$ with MS media supplemented with $\left(6.0 \mathrm{mg} \mathrm{L}^{-1}\right)$ 2,4-D + (2.0 $\left.\mathrm{mg} \mathrm{L}^{-1}\right) \mathrm{kin}$. However, MS media supplemented with $\left(0.01 \mathrm{mg} \mathrm{L}^{-1}\right) \mathrm{BA}+\left(1.0 \mathrm{mg} \mathrm{L}^{-1}\right)$ NAA exhibit new protein band $(72 \mathrm{kDa})$ in the root derived callus. The present results concluded that changes in the protein pattern appear to correlate with colocynth callus percentage and different combinations of plant growth regulators.
\end{abstract}

$\underline{\text { Key words: Colocynth, callus culture, plant growth regulators, protein profiles, PAGE-electrophoresis }}$

\section{INTRODUCTION}

Gene activation due to environmental stimuli plays an important role in the adaptation of plants to stress conditions and promotes the appearance of stress resistant specific proteins (Sachs and Ho, 1986). Analysis of protein complement of the genome includes the identification and quantification of proteins to find out which proteins are present in particular tissue which post-translational modifications occur and how protein patterns can be related to morphogenetic status of tissues. In addition, tissue culture, inclusive of in vitro cells, tissues and organs, is a convenient and effective means in physiology and biochemistry of medicinal plants and it can also contribute to production of biomass and metabolites. In vitro callus cultures of Citrullus colocynthis have been devolved from cotyledons and hypocotyls (Dabauza et al., 1997) and from stems, leaves and roots explants under different combinations from plant growth regulators (Hegazy et al., 2010). Relatively little is known about the effects of environmental conditions and developmental stage on proteins produced by plant tissues cultured in vitro (Balen et al., 2002). Callus and cell culture could not only be an alternate continue source of proteins but could also be a useful and important model system to study their regulation and biosynthesis (Podder et al., 1993) and in biochemistry studies (Serra et al., 2000). Growth regulators have an important effect on the developmental status of cells in plant tissue cultures (Meins, 1986; Satyavani et al., 2011). Biochemical markers became a popular tool in plant genetics and studies utilizing such markers were also initiated (Ramagopal, 1990). Protein and secondary metabolites of plant have been examined and were found to be promising as markers, such as water stress-induced protein (Riccardi et al., 1998). Direct evidence has shown that exogenous auxins stimulate the de novo synthesis of RNAs and proteins in particular, in plant tissue cultures (Teale et al., 2006). Although there is no information on the mechanism that activates the synthesis of specific types of RNA or the possible functions of the proteins they synthesize. Herbik et al.

Corresponding Author: Amal A. Mohamed, Department of Plant Biochemistry, National Research Centre, Dokki, Cairo, Egypt Tel: 002-02-33361225 Fax: 002-02-337610850 
(1996) investigated the effects of Fe-deficiency on protein expression in leaves and roots of tomato plant using the electrophoresis techniques. In their study, three polypeptides were increased in roots grown under $\mathrm{Fe}$ deficiency stress compared to control treatments. The authors suggested that members of this group of polypeptides are involved in the response of the root to Fe-deficiency (Ramanathan et al., 2011).

The present study petroleum ether extract of Citrullus colocynthis was evaluated petroleum ether extract of Citrullus colocynthis and its local anesthetic activity in the animal frog (Rana hexadactyla). This study proves that the leaves are equally effective as that of the synthetic standard drug xyclocaine when placed in sciatic nerve. Further studies are warranted to compare the mechanism of action.

Satyavani et al. (2011) developed a protocol for in vitro plantlet regeneration of Citrullus colocynthis using stem explants which was selected after screening of different seedling explants. Contamination free culture was established treating stem explants with $0.1 \% \mathrm{HgCl}_{2}$ for $3 \mathrm{~min}$. Optimum sucrose concentration for callus formation was $3 \%$. The role of different growth additives like pyridoxine and thiamine $\mathrm{HCl}$ was assessed in enhancing callus number. The maximum number of callus induction was achieved from stem explants on MS medium enriched with $0.5 \mathrm{mg} \mathrm{L}^{-1} \mathrm{IAA}, 2,4-\mathrm{D}$ and $1 \mathrm{ppm}$ of 6-BA which yielded morphogenic compact hard greenish white calli at a frequency of $80 \%$ than compared to MS medium enriched with other combination of auxin and cytokinin.

Cytokinins, such as kinetin have been little exploited and understood in terms of their biological activity (Roberts and Hooley, 1988). However, when total proteins from calluses grown at two cytokinin concentrations were analyzed as molecular markers of cytokinin action the protein patterns varied significantly in their level of expression according to the treatment (Renaudin et al., 1991).

Polypeptide expression varies depending upon the different developmental stages due to differential gene expression of concerned structural or regulatory genes which are under the control of master gene. The expression is albeit less influenced by media composition, explant type and culture environment (Panigrahi et al., 2007). Deletion or mutation of structural genes coding for polypeptides or their regulatory loci results in the inhibition of transcription or translation of polypeptides leading, to lack of expression of concerned polypeptides (Brown et al., 1981). Polypeptides, polymorphic for presence or absence could be potentially used as marker to decipher the differentiation pathway and selection of organogenic potential callus or tissue (Hakman, 1993).
Citrullus colocynthis (colocynth) is an important medicinal plant of family cucurbitaceae growing in Egypt and is extensively used in traditional system of medicine as a purgative, anthelmintic, carminative, anti-rheumatic, anti-diabetic and antipyretic (Maatooq et al., 1997; Nmila et al., 2000; Hegazy, 2007; Gurudeeban et al., 2010; Thirunavukkarasu et al., 2010). Since specific proteins can also be used as biochemical markers of gene expression (Potter and Jones, 1991). In the present study, we studied the relationship between changes in protein patterns which occurred in colocynth stems, leaves and roots derived callus tissues and different proportions of auxin and cytokinin in the culture medium. The interest in the present study is based on the fact that plant tissue and cell cultures could be a useful and important tool to study biochemical parameters associated with the cell growth such as, intracellular levels of proteins.

\section{MATERIALS AND METHODS}

Plant material and tissue culture: Stems, leaves and roots of colocynth in vitro raised seedlings were used as explants source as reported by Hegazy et al. (2010). Callus cultures were initiated on MS-medium (Murashige and Skoog 1962) supplemented with different combinations of 2, 4-D with Kin and BA with NAA in different concentrations as presented in Table 1. The cultures were incubated for callus induction in the growth chamber at $24 \pm 2^{\circ} \mathrm{C}$ under a fluorescent light $\left(80 \mu \mathrm{E} / \mathrm{m}^{2} / \mathrm{sec} /\right)$ at a 16-h photoperiod for three weeks.

Factors evaluated: After 21 days growth, callus cultures were taken up for determination of callusing frequency as well as protein profile by SDS-PAGE analysis against in vitro raising seedlings stems, leaves and roots which used as controls.

Callusing frequency: The frequency of callus induction was calculated according to the following formula:

$$
\text { Callus induction frequency }(\%)=\frac{\text { No. of seeds produced calli }}{\text { No. of seeds cultured }} \times 100
$$

Table 1: MS Media supplemented with different concentration of growth regulators for callus induction of Citrullus colocynthis

\begin{tabular}{lc}
\hline Media codes & Growth regulators concentration $\left(\mathrm{mg} \mathrm{L}^{-1}\right)$ \\
\hline MD1 & $\mathrm{MS}+2.02,4-\mathrm{D}+1.0 \mathrm{KIN}$ \\
MD2 & $\mathrm{MS}+1.02,4-\mathrm{D}+1.0 \mathrm{KIN}$ \\
MD3 & $\mathrm{MS}+6.02,4-\mathrm{D}+2.0 \mathrm{KIN}$ \\
MD4 & $\mathrm{MS}+2.02,4-\mathrm{D}+4.0 \mathrm{KIN}$ \\
MB1 & $\mathrm{MS}+0.0 \mathrm{BA}+5.0 \mathrm{NAA}$ \\
MB2 & $\mathrm{MS}+0.01 \mathrm{BA}+1.0 \mathrm{NAA}$ \\
MB3 & $\mathrm{MS}+0.1 \mathrm{BA}+5.0 \mathrm{NAA}$ \\
MB4 & $\mathrm{MS}+1.0 \mathrm{BA}+0.1 \mathrm{NAA}$ \\
\hline
\end{tabular}


Table 2: Callusing frequency (\%) of different explants derived from seedlings of colocynth cultured on MS- medium supplemented by different combinations of growth regulators

\begin{tabular}{|c|c|c|c|c|}
\hline \multirow[b]{2}{*}{ Growth regulators treatments } & \multirow[b]{2}{*}{ Media codes } & \multicolumn{3}{|c|}{ Explant types } \\
\hline & & Stems & Leaves & Roots \\
\hline \multirow[t]{4}{*}{$2,4-\mathrm{D}+\mathrm{kin}$} & MD1 & $94.9 \pm 1.80^{\circ}$ & $68.6 \pm 1.81^{b}$ & $26.8 \pm 1.41^{\mathrm{a}}$ \\
\hline & $\mathrm{MD} 2$ & $98.9 \pm 1.10^{g}$ & $86.4 \pm 1.38^{f}$ & $61.1 \pm 0.95^{\mathrm{d}}$ \\
\hline & $\mathrm{MD} 3$ & $83.2 \pm 2.17^{b}$ & $70.5 \pm 1.78^{c}$ & $44.2 \pm 0.96^{b}$ \\
\hline & MD4 & $98.8 \pm 1.20^{g}$ & $47.8 \pm 0.82^{\mathrm{a}}$ & $45.2 \pm 1.29^{\circ}$ \\
\hline \multirow[t]{4}{*}{$\mathrm{BA}+\mathrm{NAA}$} & MB1 & $85.1 \pm 1.73^{\mathrm{c}}$ & $85.0 \pm 1.30^{\circ}$ & $68.6 \pm 1.58^{e}$ \\
\hline & MB2 & $81.8 \pm 1.42^{\mathrm{a}}$ & $74.3 \pm 1.48^{\mathrm{d}}$ & $77.8 \pm 1.62^{\mathrm{f}}$ \\
\hline & MB3 & $97.9 \pm 1.38^{f}$ & $98.2 \pm 1.17^{\mathrm{h}}$ & $91.7 \pm 1.80^{g}$ \\
\hline & MB4 & $90.9 \pm 1.90^{d}$ & $92.6 \pm 1.53^{\mathrm{g}}$ & $92.9 \pm 1.50^{h}$ \\
\hline $\mathrm{LSD} \leq 0.05$ & & 0.699 & 0.324 & 0.281 \\
\hline
\end{tabular}

Data represents Mean \pm SD of 10 replicates per treatment in three repeated experiments. Values with different superscript letters in the same column were signific antly different $(\mathrm{p} \leq 0.05)$

Protein extraction: Fresh samples $(0.5 \mathrm{~g})$ were homogenized with $2 \mathrm{~mL}$ of $250 \mathrm{mM}$ Tris-sucrose buffer $(\mathrm{pH} 7.2)$ in a chilled pestle and mortar at $4^{\circ} \mathrm{C}$. The homogenate was centrifuged in a refrigerated centrifuge (Hermle, Germany) at $12.000 \mathrm{rpm}$ for $20 \mathrm{~min}$. Protein concentration in the supernatant samples was estimated according to the method of Bradford (1976). The supernatants were used for SDS-PAGE analysis.

Analysis of protein profile by SDS-PAGE: Supernatant samples $(40 \mu \mathrm{g}$ protein) were mixed with equal volumes of solubilizing buffer $[62.5 \mathrm{~mm}$ Tris- $\mathrm{HCl}, \mathrm{pH} 6.8,20 \%(\mathrm{w} / \mathrm{v})$ glycerol, 2\% (w/v) SDS, 5\% (v/v) 2-mercaptoethanol and $0.01 \%$ bromophenol blue] and heated for $4 \mathrm{~min}$ at $95^{\circ} \mathrm{C}$, cooled on ice before loading on $12.5 \%$ polyacrylamide slab gels. Gels were made according to Laemmli (1970). A $12.5 \%$ separating gel containing $375 \mathrm{~mm}$ Tris- $\mathrm{HCl}, \mathrm{pH} 8.8$, $0.1 \%(\mathrm{w} / \mathrm{v}) \mathrm{SDS}, 0.05 \%(\mathrm{w} / \mathrm{v})$ ammonium persulfate and $0.4 \mu \mathrm{L}$ TEMED was used for resolving the polypeptides. Whereas a $4 \%$ stacking gel containing $125 \mathrm{~mm}$ Tris- $\mathrm{HCl}$, $\mathrm{pH} 6.8,0.1 \%(\mathrm{w} / \mathrm{v}) \mathrm{SDS}, 0.05 \%(\mathrm{w} / \mathrm{v})$ ammonium persulfate and $0.5 \mu \mathrm{L}$ TEMED was used to concentrate (stack) the polypeptides. The electrophoresis running buffer consisted of $25 \mathrm{~mm}$ Tris, $192 \mathrm{~mm}$ glycine and 0.1\% SDS, $\mathrm{pH}$ 8.3. Electrophoresis was accomplished at $35 \mathrm{~mA}$ for $4 \mathrm{~h}$ using a Hoefer SE 600 series electrophoresis system.

The gels were stained with $0.25 \%$ Coomassie Brilliant Blue R-250 (Sigma) in 50\% (v/v) methanol and 10\% (v/v) acetic acid overnight and destained with acetic acid: methanol: water as follow $(2: 12: 28 \mathrm{v}: \mathrm{v}: \mathrm{v})$ until the background was clear. The gels were photographed and scanned and analyzed with labimage software (www.labimage.com). The protein molecular weight marker from Pierce was used. The standard proteins were as follows in dalton: Myosin (208.000), Phosphorylase B (112.000), BSA (85.000), Ovalbumin (48.000), Carbonic anhydrase (32.000), Trypsin Inhibitor (26.000) and Lysozyme (18.000).
Statistical analysis: All data are reported as mean $\pm \mathrm{SD}$ for the three independent samples $(n=3)$. Analysis of variance and significant differences among means were tested by one-way ANOVA using the COSTAT computer package. The Least Significant Difference (LSD) at $\mathrm{p}=0.05$ level was calculated.

\section{RESULTS AND DISCUSSION}

Callusing frequency: The callus cultures were initiated from different explants such as stems, leaves and roots segments of colocynth and grown on MS media supplemented with different concentrations and combinations of growth regulators $(2,4-\mathrm{D} / \mathrm{kin}$ and $\mathrm{BA} / \mathrm{NAA}$ ). It is clear that the different combination of growth regulators behaved in different ways. The results presented in Table 2 showed that the stem explants grown on MD2 gave the highest frequency of callus formation (98.9\%). Generally, among all 2,4-D and kin combinations treatments, the media (MD2) showed significant superiority for the frequencies of callus formation among the three studied explants. These results are in support with Hegazy et al. (2010) who reported that kin concentration outweighs the 2,4-D in the MS media produced significant effects on the callus induction (fresh and dry weight) in both stem and root explants of colocynth. Also, Shahsavari et al. (2010) showed that the presence of 2,4-D in culture medium is vital for rice callus induction frequency from mature seeds. They stated that using merely 2,4-D in culture medium for rice callus gave the highest response of $77.9 \%$ while combination of $2,4-\mathrm{D}$, NAA and Kin led to the lowest callus induction frequency of $65.8 \%$. Moreover, Dabauza et al. (1997) studied the effect of 6-benzylaminopurine (6-BA) alone or in combination with Naphthaleneacetic Acid (NAA) or Indoleacetic Acid (IAA) on callus frequency of cotyledon explants of Citrullus colocynthis (L.) Schrad. They found that the highest frequency $(81.8 \%$ ) was obtained with a 
medium containing $25 \mathrm{mM}$ 6-BA. Similarly, Yogananth et al. (2009) demonstrated that the highest percentage of callus induction (86.7\%) induced from young leaves of Solanum nigrum (Linn.) was observed when MS medium containing NAA $\left(3 \mathrm{mg} \mathrm{L}^{-1}\right)$ and BAP $\left(0.5 \mathrm{mg} \mathrm{L}^{-1}\right)$ were used. The exact molecular function of plant growth regulators in tissue culture is unclear; however, it may probably be involved in the reprogramming of the expression of embryogenic genes (Ge et al., 2006).

Protein electrophoretic pattern of different colocynth tissues: Electrophoretic patterns of stems derived callus proteins were analyzed by SDS-PAGE as shown in Fig. 1. As a result of 2,4-D and kin treatments, two polymorphic bands with high molecular weight were appeared. These bands were found at $126 \mathrm{kDa}$ in MD1 and MD4 and at $121 \mathrm{kDa}$ in $\mathrm{MD} 1, \mathrm{MD} 2$ and MD4. Moreover, two unique protein bands were expressed at $65 \mathrm{kDa}$ in MD3 and at 57 $\mathrm{kDa}$ in MD2 media (these bands might be used as a biomarker to stems derived calli under the effect of 2,4-D and kin treatment). In addition, two polymorphic bands (105 and $64 \mathrm{kDa}$ ) were specific for both $\mathrm{MB} 1$ and MB2 media. Also, one polymorphic high molecular weight protein band $113 \mathrm{kDa}$ was expressed only in MB3 and MB4 media. Two unique protein bands with low molecular weight (18 and $14 \mathrm{kDa}$ ) were expressed only in colocynth in vitro seedlings stems which used as control.

Protein SDS-PAGE analysis of leaves derived callus revealed 24 distinct protein bands with molecular weights ranged from 152 to $15 \mathrm{kDa}$ (Fig. 2). Out of these, seven polymorphic bands with molecular weights $(87,69,65,43$, 38,16 and $14 \mathrm{kDa}$ ) were expressed commonly in all treatments of growth regulators and in vitro seedlings leaves which used as control. Whereas, four polymorphic protein bands with high molecular weights were expressed under 2,4-D and kin treatments, where $152 \mathrm{kDa}$ was specific for MD2 and MD3, 145 and $136 \mathrm{kDa}$ for MD1, MD2 and MD3 and $107 \mathrm{KDa}$ for MD1, MD3 and MD4. Moreover, protein band with molecular weight $112 \mathrm{kDa}$ was expressed only in MD1. The BA and NAA treatments lead to absence of protein bands with molecular weights $(152,136,112,107,101$ and $76 \mathrm{kDa})$ in all the four media. In addition, the in vitro seedling leaves which used as control showed tow unique specific protein bands with molecular weights ( 58 and $32 \mathrm{kDa}$ ).

As shown in Fig. 3, there are five unique protein bands were specific expressed in root derived callus as a result of different growth regulators treatments. Out of theses, protein bands with molecular weights $(82,81$ and $66 \mathrm{kDa}$ ) were specific only for 2,4-D and kin treatments which expressed in $\mathrm{MD} 3, \mathrm{MD} 1$ and $\mathrm{MD} 4$ respectively.

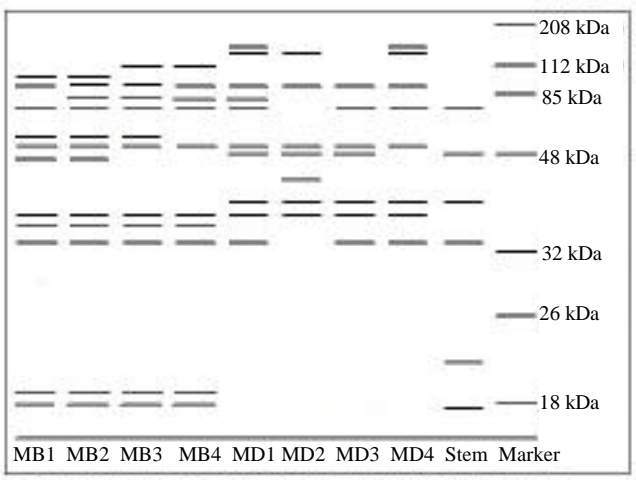

Fig. 1: SDS-PAGE patterns of colocynth stems derived callus grown on MS-medium supplemented by different combinations of growth regulators

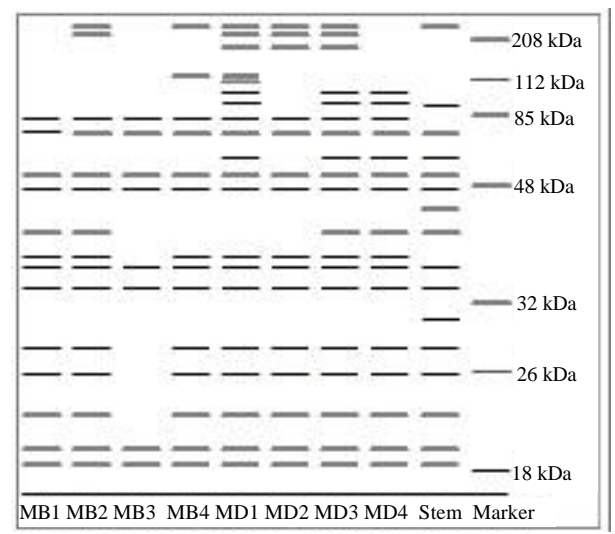

Fig. 2: SDS-PAGE patterns of colocynth leaves derived callus grown on MS-medium supplemented by different combinations of growth regulators

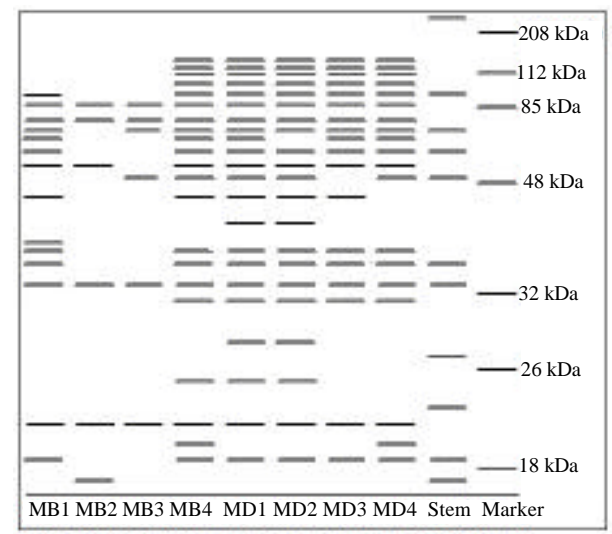

Fig. 3: SDS-PAGE patterns of colocynth roots derived callus grown on MS-medium supplemented by different combinations of growth regulators 
Whereas, protein bands with molecular weights (72 and $47 \mathrm{kDa}$ ) were specific for BA and NAA treatments and expressed only in $\mathrm{MB} 2$ and $\mathrm{MB} 1$ respectively (might be used as a biomarker to roots derived calli under the effect of BA and NAA treatment). Moreover, three protein bands with molecular weights $(153,26$ and $20 \mathrm{kDa})$ were expressed only in the in vitro seedlings roots.

Involvement of growth regulators in the induction of alteration in protein patterns was attributed to their role in controlling cell division in the apical meristems by regulating certain genes namely prolifera or cyclins (Springer et al., 1995; Takeuchi et al., 1995). The present investigation indicated that the different combinations of plant growth regulators affects changes in the protein pattern of colocynth callus. In this concern, Silva et al. (2005) observed that protein bands with molecular weights between 94 and $20 \mathrm{kDa}$ appeared in Glycine wightii callus cultures grown on MS media supplemented with ( $4.52 \mathrm{mM}) 2$,4-D and $(0.46 \mathrm{mM})$ kinetin as a response to mechanisms of growth regulators. Moreover, Renaudin et al. (1991) reported that the protein patterns varied significantly in their level of expression according to the cytokinin treatment in protoplast derived Petunia hybrida callus. The present investigation further indicated that different protein bands, shown in different explant (leaves, stems and roots) derived callus as a response to different combinations of growth regulators indicate differential gene expression. In this respect, Brown et al. (1981) stated that deletion or mutation of structural genes coding for polypeptides or their regulatory loci results in the inhibition of transcription or translation of polypeptides leading to lack of expression of concerned polypeptides. The polypeptides expression is albeit less influenced by media composition, explant type and culture environment (Panigrahi et al., 2007). Mikolajczyk et al. (2000) reported that application of Salicylic Acid (SA) induce synthesis of heat shock proteins in tobacco plants and fast activation of $48 \mathrm{kDa}$ protein Kinase in suspension cell culture of tobacco under osmotic stress.

\section{CONCLUSIONS}

The present work concluded that the different combinations of growth regulators have significantly interfered with the protein expression of Citrullus colocynthis callus cultures. This interference took place either by induction or repression of protein expression which may occur either on transcriptional or translational level. The protein expression differences may be caused by certain biochemical alterations at the cellular level of the studied callus cultures.

\section{REFERENCES}

Balen, B., J. Milosevi and M. Krsnik-Rasol, 2002. Protein and glycoprotein patterns related to morphogenesis in Mammillaria gracillis pfeiff. tissue culture. Food Technol. Biotechnol., 40: 275-280.

Bradford, M.M., 1976. A rapid and sensitive method for the quantification of microgram quantities of protein utilizing the principle of protein-dye binding. Anal. Biochem., 72: 248-254.

Brown, J.W.S., F.A. Bliss and T.C. Hall, 1981. Linkage relationships between genes controlling seed proteins in French bean. TAG Theor. Applied Genet., 60: $251-259$.

Dabauza, M., M. Bordas, A. Salvador, L.A. Roig and V. Moreno, 1997. Plant regeneration and Agrobacterium-mediated transformation of cotyledon explants of Citrullus colocynthis (L.) Schrad. Plant Cell Rep., 16: 888-892.

Ge, X., Z. Chu, Y. Lin and S. Wang, 2006. A tissue culture system for different germplasms of indica rice. Plant Cell Rep., 25: 392-402.

Gurudeeban, S., K. Satyavani and T. Ramanathan, 2010. Bitter apple (Citrullus colocynthis): An overview of chemical composition and biomedical potentials. Asian J. Plant Sci., 9: 394-401.

Hakman, I., 1993. Embryology in Norway spruce (Picea abies): An analysis of the composition of seed storage proteins and deposition of storage reserves during seed development and somatic embryogenesis. Physiologia Plantarum, 87: 148-159.

Hegazy, A.K., 2007. Conservation and sustainable use of medicinal plants. Final Report, UNDP, GEF and EEAA, pp: 337.

Hegazy, A.K., M.A. Amal, S.I. Ali and M.M. Saker, 2010. Enhancement of callus induction and cucurbitacin content in Citrullus colocynthis L. (Schrad) using plant growth regulators. J. Alabama Acad. Sci., 81: 23-35.

Herbik, A., A. Giritch, C. Horstmann, R. Becker, H.J. Balzer, H. Baumlein and U. Stephen, 1996. Iron and copper nutrition dependent changes in prolin expression in a tomato wild type and incotianamine free mutant chloronerva. Plant Physiol., 111: 533-540.

Laemmli, U.K., 1970. Cleavage of structural proteins during the assembly of head of bacteriophage $\mathrm{T}_{4}$. Nature, 227: 680-685.

Maatooq, G.T., S.H. El-Sharkawy, M.S. Afifi and P.N. Rosazza, 1997. C-p-Hydroxybenzoyl glycoflavanones from Citrullus colocynthis. Phytochemistry, 44: 187-190. 
Meins, F.J.R., 1986. Determination and Morphogenetic Competence in Plant Tissue Culture. In: Plant Cell Culture Technology, Yeoman, M.M. (Eds.). Blackwell Scientific Publication, Oxford, pp: 7-25.

Mikolajczyk, M., O.S. Awotunde and G. Muszynska, 2000. Osmotic stress induces rapid activation of a salicylic acid-induced protein kinase and a homolog of protein kinase ASK1 in tobacco cell. Plant Cell, 12: 165-178.

Murashige, T. and F. Skoog, 1962. A revised medium for rapid growth and bio assays with tobacco tissue cultures. Physiol. Plant., 15: 473-497.

Nmila, R., R. Gross, H. Rchid, M. Roye and M. Manteghetti et al., 2000. Insulinotropic effect of Citrullus colocynthis fruits extract. Planta Med., 66: 418-423.

Panigrahi, J., D.R. Kumar, M. Mishra, R.P. Mishra and P. Jena, 2007. Genomic relationships among 11 species in the genus Cajanus as revealed by seed protein (albumin and globulin) polymorphisms. Plant Biotechnol. Reports, 1: 109-116.

Podder, K.S., I. D'Silva and C.S. Vaidyanathan, 1993. Ribosome-inactivating proteins and agglutinins from callus and suspension cultures of Ricinus communis L. and Abrus precatorius L. Plant Sci., 94: 161-172.

Potter, R.H. and M.G.K. Jones, 1991. Molecular Analysis of Genetic Stability. In: In vitro Methods for Conservation of Plant Genetic Resources, Doods, J.H. (Eds.). Chapman and Hall, London, pp: 71-91.

Ramagopal, S., 1990. Protein polymorphism in sugarcane revealed by two-dimensional gel analysis. Theor. Applied Genet., 79: 297-304.

Ramanathan, T., S. Gurudeeban and K. Satyavani, 2011. Local anesthetic effect of Citrullus colocynthis on rana hexadactyla. Res. J. Med. Plant, 5: 338-342.

Renaudin, J.P., C. Tournaire and B.J. de La-Serve, 1991. Quantitative analysis of protein changes during meristem initiation and bud development in protoplast derived Petunia hybrida callus. Physiologia Plantarum, 82: 48-56.

Riccardi, F., P. Gazeau, D. De Vienne and M.M. Zivy, 1998. Protein changes in response to progressive water defi-cit in maize. Plant Physiol., 117: 1253-1263.

Roberts, J.A. and R. Hooley, 1988. Receptors Sites of Perception or Deception. In: Plant Growth Regulators, Roberts, J.A. and R. Hooley (Eds.). Blackie and Son Ltd., New York, pp: 134-150.
Sachs, M.M. and T.H.D. Ho, 1986. Alteration of gene expression during environmental stress in plants. Annu. Rev. Plant Physiol., 37: 363-376.

Satyavani, K., T. Ramanathan and S. Gurudeeban, 2011. Effect of plant growth regulators on callus induction and plantlet regeneration of bitter apple (Citrullus colocynthis) from stem explants. Asian J. Biotechnol., 3: 246-253.

Serra, A.G.P., R. Paiva and P.D.O. Paiva, 2000. Analises bioquímicas de calos formados de explantes foliares de castanha-do-Brasil (Bertholletia excelsa H.B.K.). Ciencia e Agrotecnologia, 24: 833-840.

Shahsavari, E., A.A. Maheran, A.S.N. Akmar and M.M. Hanafi, 2010. The effect of plant growth regulators on optimization of tissue culture system in Malaysian upland rice. Afr. J. Biotechnol., 9: 2089-2094.

Silva, A.L.C., C.S. Caruso, R.A. Moreira and A.C.G. Horta, 2005. Growth characteristics and dynamics of protein synthesis in callus cultures from Glycine wightii (Wight and Arn.). Verdc. Cienc Agrotec, 29: 1161-1166.

Springer, P.S., W.R. McCombie, V. Sundaresan and R.A. Martienssen, 1995. Gene trap tagging of PROLIFERA, an essential MCM2-3-5-like gene in Arabidopsis. Science, 268: 877-880.

Takeuchi, Y., Y. Omigusa, M. Ogasawara, K. Yoneyama, M. Konni and A.D. Worsham, 1995. Effects of brassinosteroids on conditioning and germination of clover broomrape (Orobanche minor) seeds. Plant Growth Regulators, 16: 152-160.

Teale, W.D., I.A. Paponov and K. Palme, 2006. Auxin in action: Signalling, transport and the control of plant growth and development. Nature Rev. Mol. Cell Biol., 7: 847-859.

Thirunavukkarasu, P., T. Ramanathan, N. Ravichandran and L. Ramkumar, 2010. Screening of anti-microbial effect in watermelon (Citrullus sp.). J. Biol. Sci., 10: 682-685.

Yogananth, N., R. Bhakyaraj, A. Chanthuru, S. Parvathi and S. Palanivel, 2009. Comparative analysis of solasodine from in vitro and in vivo cultures of Solanum nigrum Linn. Kathmandu Univ. J. Sci. Eng. Technol., 5: 99-103. 